\title{
DINAMIKA PERUBAHAN KONSTITUSI MELALUI KEBIASAAN KETATANEGARAAN DAN PUTUSAN HAKIM
}

\author{
M Rizqi Azmi ${ }^{1}$
}

\begin{abstract}
ABSTRAK
Dinamika perkembangan dan pertumbuhan masyarakat di seluruh dunia, termasuk Indonesia, menuntut adanya perubahan terhadap suatu konstitusi dari suatu negara tersebut. Adanya perubahan pola pikir dari suatu masyarakat yang diiringi dengan perubahan sistem ketatanegaraan dari suatu negara, akan menyebabkan beberapa aturan lama dari suatu konstitusi tersebut perlu disesuaikan dengan kondisi kehidupan kekinian.Suatu konstitusi pada pokoknya adalah suatu landasan bagi peraturan-peraturan hukum lainnya. Disebabkan karena tingkatannya yang lebih tinggi dan juga karena merupakan landasan bagi peraturan-peraturan hukum lainnya, maka para pembentuk konstitusi biasanya menetapkan cara-cara perubahan baik dengan Kebiasaan Ketatanegaraan dan Putusan Hakim.
\end{abstract}

\section{Kata kunci: Dinamika; Kebiasaan Ketatanegaraan; Putusan Hakim.}

\section{ABSTRACT}

Formative dynamics and worldwide society growth, including Indonesia, strove for marks since changing to a constitution of that state. Mark's sense changing patterned thinking of a society that escorted by changing state administration system of a state, will cause severally long time order of that constitution needs to be adjusted by present life condition. A constitution in the first place is a base for other law regulations. Caused because level it superordinate and also since constitutes a base for another law regulations, therefore patronizing constitution usually establishes good change tricks with custom state administration and Adjudication.

Keywords: Dynamics; State Administration; Judge's Decision.

\section{PENDAHULUAN}

\subsection{Latar Belakang}

Pertumbuhan dan perkembangan konstitusi tidak selalu berpatokan dengan isi atau materi dari konstitusi tersebut, tapi juga pada proses dan tata cara penyesuaian konstitusi tersebut dengan tuntutan perubahan zaman. Hal ini disebabkan karena masyarakat dalam suatu negara akan selalu tumbuh dan berkembang sesuai dengan perkembangan ilmu pengetahuan dan tekhnologi, termasuk juga pola pikir dari suatu masyarakat tersebut. Dinamika perkembangan dan pertumbuhan masyarakat di seluruh dunia, termasuk Indonesia, menuntut adanya perubahan terhadap suatu konstitusi dari suatu negara tersebut. Adanya perubahan pola pikir dari suatu

\footnotetext{
${ }^{1}$ Dosen Fakultas Hukum, Universitas Islam Riau, Email: mrizqiazmi@uir.law.ac.id
} 
masyarakat yang diiringi dengan perubahan sistem ketatanegaraan dari suatu negara, akan menyebabkan beberapa aturan lama dari suatu konstitusi tersebut perlu disesuaikan dengan kondisi kehidupan kekinian.

Terkait dengan perubahan konstitusi ini. Muhammad Ridhwan Indra dalam bukunya Undang-Undang Dasar 1945 Sebagai Karya Manusia, Mengemukakan² :

Dalam setiap konstitusi yang tertulis selalu tercantum suatu pasal atau pasal-pasal yang mengatur tentang perubahan konstitusi. Hal ini disebabkan oleh masyarakat yang selalu berkembang dimana selalu terjadi perubahan-perubahan serta dinamika dan struktur masyarakat. Bahkan perubahan tersebut dapat terjadi dengan sedemikian cepatnya sehingga konstitusi tersebut baik cepat atau lambat akan ketinggalan zaman. Sebab itu, dalam hal demikian konstitusi itu perlu dirubah.

Suatu konstitusi pada pokoknya adalah suatu landasan bagi peraturan-peraturan hukum lainnya. Disebabkan karena tingkatannya yang lebih tinggi dan juga karena merupakan landasan bagi peraturan-peraturan hukum lainnya, maka para pembentuk konstitusi biasanya menetapkan cara-cara perubahan yang agak sukar, dengan maksud agar orang lain tidak mudah mengubah hukum dasar suatu negara. Jikalau suatu perubahan memang diperlukan, maka perubahan tersebut haruslah dianggap benar-benar diperlukan oleh rakyat dan juga pemerintah.

Perubahan konstitusi pada dasarnya oleh George Jellinek ${ }^{3}$ dibagi menjadi dua, yaitu; pertama, melalui prosedur formal (verfassungsanderung) dan kedua, melalui cara-cara informal (verfassungswandlung). ${ }^{4}$ Perubahan formal ${ }^{5}$ adalah perubahan yang mekanismenya telah diatur di dalam konstitusi suatu negara sedangkan perubahan di luar ketentuan konstitusi disebut sebagai perubahan informal atau melalui kondisi yang disebut Djokosutono secara onbewust (lambat-laun). Menurut Soehardjo Sastrosoehardjo, verfassungsanderung dimaknai sebagai bentuk perubahan yang sesungguhnya, di mana terjadi perubahan terhadap pokok-pokok pikiran, asas-asas, bentuk negara, sistem

\footnotetext{
${ }^{2}$ Dr. Muhammad Ridhwan Indra, SH, Undang-Undang Dasar 1945 Sebagai Karya Manusia, Jakarta: Pustaka Sinar Harapan, 1990, hlm. 7.

${ }^{3}$ Astim Riyanto, Teori Konstitusi, Bandung: Penerbit Yapemdo, 2000, hlm. 581.

${ }^{4}$ Djoko Soetono, Kuliah Hukum Tata Negara, Jakarta: Penerbit In-Hill-Co, 2006, hlm. 131. dan Jimly Asshiddiqie, Pengantar Ilmu Hukum Tata Negara-Jilid I, Jakarta: Sekjen Mahkamah Konstitusi RI 2006, hlm. 145.

${ }^{5}$ Menurut Djokosoetono terdapat istilah lain yang digunakan oleh Logemann dalam membagi bentuk perubahan konstitusi; yaitu (1) functieverandering atau functiewijziging yang maknanya sama dengan verfassungsanderung, dan (2) functieverschuiving yang sama pengertiannya dengan verfassungswandlung.
} 
pemerintahan dan lainnya. ${ }^{6}$ Semenara itu, verfassungswandlung adalah perubahan makna ataupun penafsiran ketentuan dalam konstitusi yang tidak menyimpang dari ketentuan pokok serta asas-asas yang termaktub di dalamnya. ${ }^{7}$

C.F. Strong membagi verfassunganderung ke dalam beberapa cara yang umumnya ditentukan dalam konstitusi di pelbagai sistem ketatanegaraan. Cara-cara perubahan konstitusi secara formal'ala'Strong tersebut ialah: ${ }^{8}$ (a) by the ordinary legislature but under certain restrictions, perubahan melalui lembaga legislatif biasa tetapi melalui aturan-aturan tertentu, misalnya oleh Indonesia; (b) by the people through a referendum, perubahan konstitusi yang dilakukan dengan persetujuan rakyat (referendum) melalui pemungutan suara, terjadi misalnya pada masa peralihan republik keempat Prancis menuju konstitusi republik kelima di bawah pimpinan Jenderal Charles de Gaulle; (c) by a majority for all units of a federal state, sistem yang menentukan perubahan konstitusinya melalui suarasuara pada negara-negara bagian pada sebuah negara federal, terjadi misalnya pada Amerika Serikat; (d) by special convention, konvensi yang dimaksudkan dalam bagian ini bukanlah sebuah kebiasaan (convention) ketatanegaraan, melainkan adalah sebuah lembaga khusus (special convention).

Pada perubahan konstitusi secara informal, menurut K.C. Wheare, terdapat kekuatankekuatan yang mampu menimbulkan perubahan konstitusi itu sendiri. Kekuatan itu sendiri oleh Where dibagi menjadi dua, yaitu; pertama, kekuatan yang dapat menciptakan berubahnya kondisi di suatu negara. Kekuatan itu memang tidak merubah kalimat-kalimat dalam konstitusi secara eksplisit, namun kekuatan tersebut mampu menciptakan kondisi yang dapat merubah makna atau kestabilan supremasi konstitusi. Misalnya, dalam kondisi perang berkecamuk mendorong negara federal cenderung menjadi negara kesatuan. Kewenangan-kewenangan negara bagian dalam masa damai bisa berubah menjadi kewenangan negara federal dalam kondisi perang. Akibatnya, kekuasaan menjadi sangat sentralistik yang merupakan ciri pokok negara kesatuan. Hal itu menurut Wheare bukan dikarenakan berubahnya ketentuan dalam konstitusi, melainkan kondisi tersebut menyebabkan pemerintah mengabaikan konstitusi demi kepentingan yang lebih tinggi yaitu

\footnotetext{
${ }^{6}$ Djokosoetono. Op. Cit.

${ }^{7}$ Astim Riyanto, Teori Konstitusi, Op. Cit, hlm. 564.

${ }^{8}$ Ibid.
} 
perlindungan negara. Kedua, kekuatan yang mampu menciptakan kondisi sehingga terlaksananya perubahan konstitusi secara formal, melalui interpretasi hakim dan melalui konvensi atau kebiasaan ketatanegaraan.

Studi mengenai perubahan konstitusi secara informal dalam kebiasaan serawal dari Negara-negara yang tidak mempunyai konstitusi. Apabila di runut melalui sejarah maka negara Inggris yang pertama menggunakan sistim perubahan informal ini. Jika ditinjau suasana ketatanegaraan Indonesia pasca perubahan UUD $1945,{ }^{9}$ juga terdapat kemungkinan perubahan informal konstitusi, terutama sebagaimana telah dikemukakan oleh Djokosoetono dan Wheare di atas, yaitu melalui interpretasi hakim. Kehadiran Mahkamah Konstitusi (MK) membuka ruang terjadi interpretasi konstitusi oleh para hakim. Penafsiran oleh lembaga judicial tersebut diberikan melalui kewenangan pengujian produk hukum (toetsingrecht). Toetsingrecht oleh lembaga peradilan (judicial review) sendiri menimbulkan perdebatan panjang bagi para pakar hukum tata negara dipelbagai negara.

Oleh karena itu, rumusan masalah yang dapat dikaji dalam tulisan ini adalah sebagai berikut:

1. Bagaimana perubahan konstitusi melalui kebiasaan ketatanegaraan?

2. Bagaimana bentuk perubahan konstitusi melalui putusan hakim?

\section{METODE PENELITIAN}

Metode penelitian yang digunakan adalah penelitian yuridis normatif. Penelitian yuridis normatif merupakan penelitian kepustakaan atau studi dokumen, yaitu penelitian yang dilakukan atau ditujukan pada peraturan-peraturan yang tertulis atau penelitian yang didasarkan pada data sekunder. Sifat dari penelitian ini adalah deskriptif yaitu penelitian yang bertujuan untuk mengetahui analisis dan pengaturan konstitusi melalui kebiasaan Ketatanegaraan dan putusan hakim.

\footnotetext{
${ }^{9}$ Lihat Saldi Isra dan Feri Amsari, Perubahan Konstitusi Melaui Tafsir MK, Jurnal Konstitusi PUSaKO Universitas Andalas Volume 1. No. 1 November 2008, hlm, 112
} 


\section{HASIL PENELITIAN DAN PEMBAHASAN}

\subsection{Perubahan Konstitusi Melalui Kebiasaan Ketatanegaraan}

Pertama-pertama mesti harus dijelaskan perbedaan antara kata "Kebiasaan" (Usage) dan 'Tradisi' (convention). Tradisi adalah aturan yang mengikat, aturan perilaku yang diterima sebagai wajib oleh mereka yang peduli dengan jalannya Konstitusi sedangkan yang dimasud dengan kebiasaan tidak lebih dari usual practice (Praktik Biasa). Maka jelas bahwa kebiasaan bisa menjadi tradisi.Apa yang biasanya dilakukan menjadi pa yang dilakukan.Seringkali sulit mengatakan apakah suatu aturan perilaku bersifat harus atau persuasive saja dan dalam hal ini bisa dikatakan bahwa aturan ini jelas adalah kebiasaan dan mungkin atau sudah pasti, dalam kasus tertentu adalah tradisi.

Dalam menentukan apakah suatu praktek telah menjadi kebiasaan dapat juga dengan menerapkan tes empat tingkat yang apabila telah dipenuhi maka akan meningkat status dari praktek menjadi kebiasaan. Pertama, durasi, yang dituntut adalah konsistensi dan kelaziman dari praktek sangat dibutuhkan, durasi merupakan begian yang tak terpisahkan. Akan tetapi, tidak ada tuntutan untuk sebuah waktu yang lama sebagaimana telah ditunjukkan oleh Pengadilan Internasional. Kedua, kesamaan dan konsistensi praktek, kesamaan secara keseluruhan tidak dituntut, namun dituntut adanya kesamaan substansi. Ketiga, praktek yang sudah umum, yakni sebagai aspek yang melengkapi konsistensi, disinipun tidak dituntut universal, namun seberapa jauh adanya penolakan dari negara-negara dalam kaitannya dengan praktek negara-negara lain. Keempat, adalah yang dimaksud dengan opini juris yang mana disini praktek yang dilakukan tidak hanya didasarkan oleh motif lain selain adanya keyakinan dan rasa wajib untuk mematuhi kebiasaan tersebut sebagai bagian dari kewajiban hukum. ${ }^{10}$

Tradisi nampaknya berasal dari paling tidak dua sumber. Pertama tradisi berasal dari pola tindakan yang bisa bertahan dalam waktu yang lama dan secara bertahap akan memperoleh kekuatan yang bersifat persuasif dan kemudian berubah menjadi kekuatan yang bersifat mengikat.Umumnya, kita menyebut jenis tradisi ini dengan 'adat' (Custom), tetapi tradisi bisa lahir lebih cepat lagi.Kedua, Bisa saja tradisi lahir dari persetujuan dari orang-orang yang telah sepakat melakukan sesuatu dengan cara tertentu dan mengambil aturan perilaku tertentu.Aturan ini kemudian bersifat mengikat dan ini menjadi tradisi. Proses men-tradisikan prilaku ini tidak

\footnotetext{
${ }^{10}$ Jawahir Thontowi, Hukum International Kontemporer, Bandung: PT Refika Aditama, 2006, hlm. 63.
} 
lahir dari adat, ia tidak mempunyai sejarah sebelumnya sebagai kebiasaan. Akan tetapi Ia tumbuh dari kesepakatan. Dasarnya jelas mirip sekali dengan dasar dari konvensi yang dibangun dalam hubungan Internasional. Ia dianggap mengikat secara moral dan politik, tetapi sebelum ia ditetapkan oleh perangkat Negara yang berwenang, di sebagian besar Negara ia tidak bisa menggantikan Hukum atau menjadi bagian dari Hukum.

Kebiasaan dan tradisi menunjukkan pengaruhnya adalah dalam membatalkan ketentuan konstitusi, atau dengan kata lain konstitusi melumpuhkan senjata hukum. Disini tradisi tidak mengamandemen atau menghapus hukum, ia tidak memotong bagian tubuh tapi membuat bagian tubuh itu tidak dapat digunakan. Contoh bagaimana Tradisi dan Kebiasan dapat mengubah Konstitusi dapat dilihat dari berbagai kasus, adalah sebagai berikut: ${ }^{11}$

1. Raja tidak berkuasa lagi dalam memveto RUU

Contohnya Dalam Konstitusi Denmark, Norwegia, dan Swedia, Raja diberi kekuasaan untuk menolak hukum-hukum yang disampaikan oleh legislative. Tetapi di Tiga negara tersebut sekarang sudah disepakati bahwa Raja tidak bisa lagi menggunakan kekuasaan ini. Kejadian terakhir Raja menggunakan Kekuasaan ini terlihat pada Raja Denmark menolak RUU pada Tahun 1912 dan Raja Swedia memveto RUU pada Tahun 1912, inipun dilakukan atas desakan dari menteri-menterinya. Demikian pula di Belanda dan Belgia kekuasaan raja untuk memveto legislasi telah dihapuskan oleh tradisi.

Selanjutnya juga ditemukan dalam sebagian Konstitusi negara-negara Persemakmuran yang dalam pasal Konstitusinya memberikan kekuasaan pada Gubernur-Jenderal untuk menolak Undang-undang yang disampaikan oleh parlemen anggota-anggota persemakmuran. Kekuasaan ini ditemukan, misalnya dalam Konstitusi Kanada, Australiadan Selandia Baru. Namun, dengan tradisi disepakati bahwa Raja tidak akan mengambil tindakan pada RUU yang tindakan tersebut akan bertentangan dengan keinginan pemerintah anggota-anggota Persemakmura, sehingga penggunaan kekuasaan ini tidak dimungkinkan lagi.

2. Presiden tidak dapat lagi membubarkan Dewan Perwakilan Rakyat (Chamber of Deputies

\footnotetext{
${ }^{11}$ Lihat K. C. Wheare, Konstitusi-Konstitusi Modern, Surabaya: Pustaka Eureka, 2005, hlm. 183-203.
} 
Salah satu contoh menarik tentang bagaimana hukum bisa dibatalkan oleh konstitusi dapat kita lihat Konstitusi Republik Perancis III. Salah satu pasal dalam konstitusi ini menyebutkan bahwa presiden republic, dengan persetujuan Senat, dapat membubarkan Dewan Perwakilan Rakyat (Chamber of Deputies). Kekuasaan ini digunakan sekali pada tahun 1877, sesudah berdirinya republik, oleh presiden Mc Mahon dan tidak pernah atau tidak pantas digunakan lagi. Kenyataan dimana Mc Mahon membubarkan Dewan dan kontroversi yang terjadi sesudahnya memperlihatkan bahwa upaya yang dilakukan oleh presiden untuk membubarkan menjadi serangan pada rezim republik. Dengan demikianPresiden menduduki tempat dalam konstitusi yang sebanding dengan kedudukan raja dalam kerajaan yang demokratis, dan kekuasaannya untuk melakukan jenis tindakan ini menjadi batal.

\section{Pembatasan Pemilihan Presiden}

Dalam Konstitusi Republik Ketiga Perancis dan Amerika Serikat memberikan contoh yang menarik dalam pembatasan yang ditetapkan oleh tradisi pada pemilihan kembali jabata presiden. Dalam Konstitusi Republik Ketiga Perancis disebutkan bahwa Presiden Republik dipilih oleh mayoritas mutlak dalam sidang bersama senat dan Majelis Perwakilan Rakyat, dan Ia berhak dipilih kembali. Dalam Konstitusi Amerika Serikat tidak ada pembatasan pada hak Presiden untuk dipilih kembali. Akan tetapi di Perancis dan Amerika Serikat tumbuhlah tradisi menentang kembali bagi masa jabatan presiden yang kedua dan yang ketiga. Presiden Perancis mengakui hal ini dengan mengumumkan menjelang pemilu bahwa ia tidak akan mencalinkan diri untuk dipilih kembali. Di Amerika Serikan selaluada keragauan apakah Wakil Presiden yang naik menggantikan Presiden ketika Presiden meninggal dunia, dan karenanya bisa mengklaim bahwa ia belum dipilih sebagai Presiden dan belum menjalankan masa jabatan Presiden secara penuh, bisa mengikuti pemilihan bagi dua masa Presiden sebagai bagian dari haknya sendiri, tetapi terlepas dari kesimpangsiuran ini, tidak diragukan ada tradisi menentang jabatan Presiden untuk ketiga kalinya. 
4. Tradisi memungkinkan adanya transfer kekuasaan

Meskipun tradisi kadang membatalkan hukum konstitusi dan menyebabkan kekuasaan yang diberikan tidak mungkin dijalankan sama sekali, tradisi tidak selalu berjalan. Yang sering terjadi adalah kekuasaan yang diberikan dalam konstitusi benar-benar dijalankan, sementara hukum dijalankan oleh mereka yang diberi kekuasaan, dalam praktik kekuasaan tersebut dijalankan oleh orang atau lembaga lain.

Banyak negara yang memberikan kekuasaan kepada Raja untuk mengangkat menterimenteri menurut keinginannya sendiri, akan tetapi dalam praktiknya Raja mengangkat orang-orang yanga direkomendasikan oleh Perdana Menteri. Hal ini menunjukkan bahwa Raja menjalankan kekuasaan hukum yang diberikan kepadanya dalam Konstitusi, tidak dalam persolan pembatalan kekuasaan hukum yang ada padanya, akan tetapi pelaksanaannya dilakukan atas saran dari Perdana Menteri.

Disebagian besar negara yang mempraktikkan pemerintahan kebinet atau sistem eksekutif parlemen, didapati bahwa tradisi bisa memindahkan kekuasaan hukum dari kepala negara kepada pihak lain dalam menjalankan roda pemerintahan. Adapun contoh menarik mengenai transfer kekuasaan hukum oleh tradisi kepada pihak lain ditemukan dalam pelaksanaan pasal-pasal dalam Konstitusi Amerika Serikat yang mengatr bagaimana Presiden dan Wakil Presiden dipilih. Kekuasaan hukum untuk memilih berda di tangan Lembaga Pemilu yang dipilih oleh disetiap negara dengan metode-metode yang ditentukan oleh legislative senat.

Akan tetepi menurut tradisi, lembaga ini tidak mempunyai kekuasaan. Kekuasaan ini diserahkan kepada organisasi pertain yang akan memutuskan siapa yang menjadi calon dan pemilihlah yang akan menentukan berdasarkan cara-cara yang diatur oleh hukum. Sehingga lembaga pemilu tak lebih dari catatan statistic suara pemilih. Benar bahwa hal ini tidak hanya diakibatkan oleh tradisi saja, ada banyak unsur persetujuan hukum dibaliknya. Tetapi tradisi, didukung oleh seluruh kekuatan organisasi partai.

5. Tradisi dan Kebiasaan berjalan sebagai pelengkap hukum.

Perbandingan yang menarik tentang bagaimana cara konstitusi berjalan untuk melengkapi hukum konstitusi dapat kita lihat dalam perbedaan status dan fungsi juru bicara di Majlis Perwakilan Rakyat Amerika dan Majlis Rendah Kanada. Tradisi yang berjalan 
menjadikan juru bicara Majlis Amerika sebagai pemimpin yang menonjol dari partai mayoritas di Majlis, sedangkan di Kanada sebaliknya karena meski tidak begitu menjauhkan diri dari politik seperti di Amerika Serikat, juru bicara Majlis Rendah di Kanada hampir tidak berkiprah di politik. Di Kanada jabatan lebih lanjut diatur menurut tradisi, karena terdapat pengertian bahwa akan digunakan dua bahasa secara bergantian dalam setiap pertemuan parlemenantara anggota berbahasa Perancis dan anggota berbahasa Inggris, dan ada ketentuan lain, tertulis dalam tata tertib, bahwa jika Juru bicara berbahasa Perancis, Wakil Juru Bicara haruslah berbahasa Inggris, atau sebaliknya. Terdapat banyak perbedaan pendapat mengenai detail jabatan ini dari suatu negara dengan negara lain, tetapi ada satu hal yang disepakati bahwa pemimpin partai tidak boleh sekaligus pemimpin partai.

Kebiasaan dan tradisi mengubah konstitusi dengan cara lain. Keduanya menjadi pelengkap hukum. Kekuasaan yang diberikan dalam hukum kepada orang atau lembaga pada kenyataannya dijalankan oleh konstitusi tersebut - kekuasaan itu tidak dibatalkan atau dipindahkan oleh tradisi - tapi ia menjadi bagian dari caranya saja.Tradisi dan kebiasaan merupakan 2 (dua) hal yang saling mempengaruhi dan saling membutuhkan. Garis batas antara keduanya sering tidak jelas dan terkadang sulit memutuskan apakah keputusan tertentu mesti tertulis dalam hukum Konstitusi atau apakah ia bisa diatur menurut kebiasaan atau tradisi.

Hubungan erat antar kebiasaan dan tradisi di satu pihak dan hukum Konstitusi di pihak lain akan nampak lebih jelas ketika menemui kasus-kasus dimana tradisi berubah menjadi hukum, mungkin dengan dimasukkannya tradisi melalui amandemen Konstitusi itu sendiri. Ini mungkin dianggap perlu mungkin karena hukum, dalam beberapa hal, dianggap memiliki otoritas yang lebih kuat dari tradisi, atau mungkin juga bahwa tradisi diperselisihkan dan langkah yang paling baik untuk menyelesaikannya adalah dengan membuat peraturan.

Satu karakteristik yang terdapat dalam banyak contoh berjalannya tradisi, sebagaimana yang digambarkan oleh Dicey dalam bukunya Law of Constitution ketika ia menjelaskan tradisi dalam pemerintahan Inggris bahwa tradisi-tradisi tersebut dimaksudkan untk menjamin supremasi tertinggi dari orang-orang yang berhak memilih sebagai satu-satunya 
pemegang kedaulatan politik negara. Gambaran tentang pengaruh tradisi juga ditunjukkan di negara selain Inggris.

a. Perubahan Konstitusi Melalui Putusan Hakim

Kasus Madison Vs Marbury (1803) dalam ilmu hukum, khususnya Hukum Tata Negara juga dipahami sebagai formula awal dari ide perubahan konstitusi melalui penafsiran oleh lembaga peradilan/hakim..$^{12}$

Kasus ini diawali dengan kekalahan presiden John Adams dari Partai Federal (The Federalist Party) dalam pemilihan umum (pemilu) presiden Amerika Serikat dari saingannya Thomas Jefferson dari partai Demokratik Republik. Medison merupakan seorang sekretaris negara (the secretary of the state), orang pilihan dari John Adams dalam menguatkan kekuatannya dalam struktur kenegaraan presiden Thomas Jefferson yang baru, sedangkan William Marbury dan rekan-rekannya adalah calon hakim perdamaian (justice for peace) di daerah Washington, distrik Colombia yang diusung oleh John Adams kepada senat pada malam akhir kepemimpinannya di Gedung Putih yang pengangkatannya ditahan.

Kondisi ini membuat William Marbury CS. Mengajukan gugatan kepada Mahkamah Agung (MA) yang dipimpin oleh John Marshal (mantan sekretrais negara pada masa John Adams). Melalui kuasa hukumnya, Charles Lee, mereka menggugat agar MA mengeluarkan "a write of mandamus", sebuah surat perintah yang diterbitkan MA untuk memaksa Medison agar menyerahkan surat-surat penangkatan mereka sebagai Hakim Perdamaian.

Charless Lee berpendapat bahwa Marbury dan calon hakim lainnya telah disetujui oleh kongres dan melalui keputusan Presiden John Adams dan di-cap resmi kenegaraan. Lee mengutip ketentuan UU Kekuasaan Kehakiman (the Judiciary Act) 1789 bahwa MA berwenang memutus perkara mereka dan mengeluarkan writ of mandamus. Jefferson tetap menolak dan melarang jajarannya memberikan kesaksian

${ }^{12}$ John H Garvey and T Alexander Aleinikof, Modern Constitutional Theory, Third Edition, West Publishing Co. St. Paul, Minn, 1994, hlm. 104, dinyatakan oleh Garvey dan Aleinikof bahwa ; the theory upon wicht judicial review was founded in Marbury vs. Madison 
di MA mengenai alas an mengapa writ of mandamus tidak dapat dikeluarkan oleh

MA. Peristiwa ini menghangat dan memaksa Jefferson melakukan tindakan politis.

The supreme court beranggapan dalam putusannya bahwa Marbury dan calon-calon hakim perdamaian berhak atas jabatannya tersebut dikarenakan pemerintahan John Adams telah melengkapi seluruh persyaratan penangkatan sebagaimana yang dipaparkan oleh Charless Lee. Namun MA menolak dengan mengatakan bahwa mereka tidak memiliki wewenang untuk memerintahkan pejabat negara/pemerintah untuk mengeluarkan tugas Marbury sebagai hakim perdamaian.

MA beranggapan ketentuan section 13 UU Kekuasaan Kehakiman 1789 mengenai writ of mandamus tidak dapat dibenarkan karena bertentangan dengan Article III section 2 konstitusi. Sedangkan Marshall berpedoman kepada Article III section 2 Konstitusi Amerika Serikat.

Marshall dan hakim-hakim agung lainnya mengatakan bahwa writ of mandamus tersebut bertentangan dengan konstitusi, sehingga MA menolak gugatan dan membatalkan UU KK 1789. Kewenangan membatalkan UU tidak ada dalam konstitusi, namun Marshall mengatakan bahwa sebagai supreme of law of the land maka setiap UU yang dibuat kongres apabila bertentangan dengan konstitusi harus dibatalkan.

Setelah keputusan yang memberikan kewenangan baru bagi The Supreme Court of the United States tersebut dikenal dalam dunia hukum, maka terjadilah perkembangan judicial review yang sangat beragam, namun tetap berpedoman kepada putusan terhadap kasus Marbury vs Madison ini.

Putusan Marshall tersebut menjadi awal dari pemahaman mengenai judicial review terhadap konstitusi dalam teori ketatanegaraan dunia. Menurut Mahfud MD, ada 3 (tiga) alasan John Marshall dalam menerapkan sebuah mekanisme review oleh hakim, yaitu ${ }^{13}$ :

1. Hakim bersumpah untuk menjunjung tinggi konstitusi sehingga kalau ada UU yang bertentangan dengannya maka hakim harus berani membatalkannya,

13 Moh. Mahfud MD, Membangun Politik Hukum, Menegakkan Konstitusi, Pustaka LP3ES Indonesia, 2006, hlm. 37. 
2. Konstitusi adalah the supreme law of the land sehingga harus ada lembaga pengujian terhadap peraturan yang dibawahnya agar konstitusi itu tidak diselewengkan,

3. Hakim tidak boleh menolak perkara sehingga kalau ada yang meminta uji materi, hakim harus melakukannya,

Ide yang menempatkan lembaga yudikatif sebagai lembaga yang menentukan apakah sebuah produk perundang-undangan layak diberlakukan atau tidak memang masih menimbulkan pelbagai perdebatan. H. L. A. Hart mengemukakan bahwa paham "a supreme tribunal has the last word in saying what the law is" akan menjadi terbantahkan jika putusan pengadilan tersebut adalah putusan yang salah. Putusan salah yang menghapuskan kekuatan hukum dari peraturan perundang-undangan legislatif tidak dapat dipertanggungjawabkan secara hukum dikarenakan tidak terdapat hak dan kewajiban sebagai konsekuensi dari kesalahan tersebut.

Charles L. Black bahkan menganggap bahwa keputusan Supreme Court Amerika Serikat dalam kasus Marbury Vs. Madison adalah kesalahpahaman dalam melihat fungsi lembaga yudikatif. Black menyatakan bahwa fungsi utama dari pengadilan adalah memberikan keabsahan (validation), bukan membatalkan keabsahan (invalidation) UU yang dibuat kekuasaan negara. Black memahami bahwa antara legislatif sebagai pembuat UU dan pemerintah sebagai pelaksana UU akan menimbulkan perbedaan pemahaman menafsirkan makna dari UU. Sehingga kedua lembaga (legislatif dan eksekutif) membutuhkan suatu interpretasi UU yang memiliki ukuran baku dan absah. Di sinilah letak fungsi pengadilan (yudikatif) yang mampu memberikan keabsahan interpretasi UU, bukan membatalkan keabsahan itu sendiri. Hal itu sesuai dengan pandangan Montesquieu bahwa kekuasaan legislatif, eksekutif dan yudikatif sejajar (horizontal) dan masing-masing wajib merujuk kepada ketentuan yang lebih tinggi, yaitu konstitusi (vertikal). ${ }^{14}$ Bahkan Jaakko Husa mengkritik perspektif Amerika yang beranggapan bahwa judicial review adalah cara yang paling dibutuhkan untuk menegakkan paham konstitusionalisme. ${ }^{15}$ Padahal akibat

\footnotetext{
${ }^{14}$ http://www.sinarharapan.co.id/berita/0611/06/opi01.html., diakses tanggal 24 Mei 2010.

${ }^{15}$ Joachim Sanden, Methods of Interpreting The Constitution; Estonia's Way in an Increasingly Integrated Europe, Juridica International VIII/2003, http://www.juridica.ee/get_doc.php?id=635, diakses tanggal 24 Mei 2010.
} 
pemahaman seperti itu, menurut Husa, menimbulkan persoalan terhadap legitimasi politik (legislatif maupun eksekutif). ${ }^{16}$

Sejalan dengan pemikiran tersebut K.C. Wheare memaparkan bahwa pengadilan tidak bisa mengamandemenkan Konstitusi serta tidak bisa mengubah kalimat Konstitusi. Pengadilan mesti menerima kalimat tersebut, dan sejauh pengadilan mengintrodusir perubahan, itu hanya bisa dilakukan dalam penafsiran mereka atas makna kalimat tersebut. Pengadilan, dengan keputusan - keputusannya, bisa menjelaskan kandungan kata atau kalimat, pengadilan boleh menyempurnakan, melengkapi, atau memperhalus keputusan sebelumnya. Tetapi pengadilan mesti tetap berpegang pada kalimat Konstitusi. Tetapi hal pokok yang perlu diingat bahwa fungsi hakim yang sebenarnya adalah menafsirkan, bukan mengubah kalimat dalam undang - undang dasar atau konstitusi, dan perubahan makna Konstitusi semacam ini sebagaimana yang secara syah bisa dilakukan oleh Pengadilan berasal dari fungsi untuk menafsirkan, bukan dari fungsi inheren atau melekat pada pembuatan hukum. ${ }^{17}$

Teori atau cara berpikir hakim dalam menafsirkan hukum terutama konstitusi maupun produk legislasi disebut sebagai penafsiran hakim. ${ }^{18}$ Penafsiran oleh hakim tersebut dapat dibedakan menjadi dua yaitu judicial review dan constitutional review. Pembedaan itu dilakukan dengan beberapa alasan: pertama, constitutional review bukanlah hak tunggal dari lembaga peradilan, ${ }^{19}$ wewenang uji konstitusional tersebut bergantung kepada ketentuan konstitusi masing-masing negara. Terdapat konstitusi yang memberikan uji konstitusionalitas kepada sebuah Dewan Konstitusi seperti Prancis atau oleh lembaga legislatif (MPR) yang pernah dianut Indonesia sebelum perubahan UUD 1945. Kedua, istilah judicial review dapat pula mengarah kepada uji terhadap peraturan perundangundangan di bawah undang-undang (Judicial review refers to the ultimate authority of the Supreme Court to judge whether [a] a state law or [b] a national law), ${ }^{20}$ sedangkan penggunaan istilah constitutional review hanya sesuai dengan proses uji konstitusionalitas

\footnotetext{
${ }^{16}$ Ibid.

${ }^{17}$ K.C. Wheare, Konstitusi-Konstitusi Modern, Pustaka Eureka, Surabaya, 2005, hal 159

${ }^{18}$ http://en.wikipedia.org/wiki/Judicial_interpretation. diakses tanggal 23 Mei 2010.

${ }^{19}$ Luthfi Widagdo Eddyono, "Catatan Eksplorative Perkembangan Constitutional Review", dalam Jurnal Konstitusi Mahkamah Konstitusi Republik Indonesia, Volume 2, Nomor 1, Juli 2005. tulisan ini merupakan resensi terhadap buku karangan Jimly Asshiddiqie, Model-Model Pengujian Konstitusional di Berbagai Negara, (Jakarta: Penerbit Konstitusi Press, 2005).

${ }^{20}$ http://www.historyofsupremecourt.org/history/defines/overview.htm. diakses tanggal 22 Mei 2010
} 
terhadap produk hukum di bawah konstitusi. ${ }^{21}$ Berdasarkan argumentasi di atas dapat pula digunakan istilah yang lebih tepat sebagaimana yang dikemukakan oleh Vicki C. Jackson dan Mark Tushnet yaitu constitutional judicial review, pengujian konstitusional yang dilakukan lembaga peradilan. ${ }^{22}$

Hak untuk memberikan tafsir terhadap konstitusi maupun produk hukum lainnya memang bukanlah kewenangan monopoli dari lembaga peradilan. ${ }^{23}$ Namun agar penafsiran terhadap teks konstitusi memiliki kekuatan hukum yang dapat diakui seluruh elemen negara, maka peradilan diberikan kewenangan untuk memberikan tafsir tersebut. Beberapa pakar memiliki landasan penting kenapa hanya peradilan yang berhak melakukan tafsir terhadap produk hukum.

Interpretasi atau menafsir undang-undang (wetsuitleg) menurut ajaran hukum sebenarnya adalah alat pembantu dalam memberi arti, maksud atau ratio terhadap suatu ketentuan undang-undang. ${ }^{24}$ Hal itu disebabkan ketentuan hukum tidak dapat memberikan penyelesaian terhadap permasalahan yang ada. Oleh karena itu dibutuhkan penafsir undangundang yang memahami tujuan hukum sesungguhnya dan keputusannya memiliki legitimasi untuk mengikat, maka diserahkan wewenang tersebut kepada lembaga peradilan. Apalagi dikarenakan lembaga peradilan adalah tempat terakhir mencari keadilan dan tempat penyelesaian pelbagai perkara.

Para hakim menggunakan pandangan atau kemampuan berdasarkan pemahaman mereka terhadap hukum itu sendiri. Artinya, masing-masing hakim berbeda pula dalam melakukan penafsiran konstitusi, sehingga suatu saat para hakim akan saling bertentangan dalam menafsirkan konstitusi dalam perkara tertentu. ${ }^{25}$ Namun, terdapat metode penemuan hukum melalui penafsiran oleh hakim, ialah: interpretasi gramatikal, interpretasi sitematis atau logis, interpretasi historis, interpretasi teleologis atau sosiologis. ${ }^{26}$ Pandangan Soedikno Mertokusumo tersebut umum digunakan dalam kaidah tafsir hukum secara umum. Namun, dalam metode tafsir konstitusi metode interpretasi yang digunakan sedikit berbeda walaupun pada intinya penafsiran hukum tersebut dapat pula digunakan untuk itu.

${ }^{22}$ Vicki C. Jackson dan Mark Tushnet, Comparative Constitutional Law, (New York: New York Foundation Press, 1999), hlm. 456.

${ }^{23}$ Walter Murphy, Constitutional Interpretation as Constitutional Creation: The 1999-2000 Harry Eckstein Lecture, http://repositories.cdlib.org/csd/00-05. diakses tanggal 20 Mei 2010.

${ }^{24}$ John Z. Loudoe, Menemukan Hukum Melalui Tafsir dan Fakta, Jakarta: Penerbit Bina Aksara, 1985, hlm. 82

${ }^{25} \mathrm{http} / / /$ www.landmarkcases.org/plessy/const_interp.html, diakses tanggal 20 Mei 2010.

${ }^{26}$ Soedikno Mertokusumo, Penemuan, Op. Cit. hlm. 57-61.
} 
Ada hal yang menarik untuk dipahami dalam masalah melakukan interpretasi konstitusi. Pada amandemen ke-14 (empat belas) Konstitusi Amerika terdapat jaminan kesamaan setiap warga negara di hadapan hukum (equality before the law). Poin tersebut sangat sulit diberikan tafsiran, apalagi pemahaman dari masyarakat awam bahwa persamaan di hadapan hukum tersebut adalah perlakuan yang serupa tanpa beda. Dalam hal kejadian di Amerika tersebut, terdapat beberapa pertanyaan: apakah dalam memberlakukan setiap orang sama di hadapan hukum itu berarti memperlakukannya dengan sama (identik)? atau perlakuan yang sama itu berarti diperlukan tindakan yang berbeda pada masing-masing kasus $?^{27}$ Dalam sejarah peradilan Amerika pemahaman equal tersebut menyebabkan peradilan memberikan keputusan yang berbeda-beda pula pada setiap kasus. Hal tersebut memperlihatkan bahwa di dalam konstitusi bisa saja terdapat kalimat-kalimat ambigu. Oleh karena itu, hakim memiliki peran penting untuk "menghilangkan" keraguan terhadap ketentuan konstitusi. Hal ini sesuai dengan apa yang dikemukakan oleh H. L. A. Hart, Chief Justice Hughes dari Supreme Court Amerika menyatakan bahwa "the Constitution is what the judge say it is!",28

Terdapat dua sumber sebagai landasan bagi penafsiran konstitusi ialah: ${ }^{29}$ (1) the text and structure of the Constitution, yang diperhatikan di sini adalah 'bunyi' dari ketentuan di dalam konstitusi atau juga disebut sebagai the literal approach; (2) intentions of those who drafted, voted to propose, or voted to ratify the provision in question, yang dilihat adalah maksud dibentuknya konstitusi dan pandangan dari penyusun konstitusi. Oleh karena itu, penafsir perlu memahami sejarah pembentukan sebuah konstitusi, dalam situasi seperti apa konstitusi dibentuk dan pandangan atau ideologi apa yang dianut oleh para framers of constitution. Sumber ini juga dikenal dengan sebutan the broad and purposive approach; (3) prior precedents, di sini yang diperhatikan adalah kasus-kasus terdahulu yang merupakan yurisprudensi dalam menafsirkan konstitusi terhadap kasus-kasus tertentu atau disebut juga dengan the doctrine of "harmonious interpretation"; (4) the social, political, and economic consequences of alternative interpretations, hakim dalam menafsirkan konstitusi juga mempertimbangkan faktor-faktor lain yang dapat mempengaruhi kondisi bernegara, seperti

\footnotetext{
${ }^{27}$ http://www.landmarkcases.org/plessy/const_interp.html. diakses tanggal 20 Mei 2010.

${ }^{28}$ Joachim Sanden, Methods of Interpreting, Op. Cit

${ }^{29}$ http://www.law.umkc.edu/faculty/projects/ftrials/conlaw, diakses tanggal 21 Mei 2010.
} 
kondisi politik dan ekonomi; (5) natural law, penafsiran yang bersumber pada natural law diarahkan kepada ketentuan-ketentuan agama, nilai-nilai moral yang dianut masyarakat. Penafsiran hakim atas konstitusi sesungguhnya didasari pula pada pandangan hakim terhadap konstitusi itu sendiri, apakah hakim melihat konstitusi tersebut sebagai the living constitution atau sebagai the moral constitution. ${ }^{30}$

Perubahan yang terjadi di luar ketentuan formal konstitusi yang melibatkan lembaga peradilan juga terjadi dalam praktik ketatanegaraan di Indonesia pasca amandemen UUD 1945. AdalahMahkamah Konstitusi sebagai lembaga negara yang berfungsi menangani perkara tertentu di bidang ketatanegaraan, dalam rangka menjaga konstitusi agar dilaksanakan secara bertanggung jawab sesuai dengan kehendak rakyat dan cita-cita demokrasi. Keberadaan Mahkamah Konstitusi sekaligus untuk menjaga terselenggaranya pemerintahan negara yang stabil, dan juga merupakan koreksi terhadap pengalaman kehidupan ketatanegaraan di masa lalu yang ditimbulkan oleh tafsir ganda terhadap konstitusi. Kewenangan konstitusional Mahkamah Konstitusi melaksanakan prinsip checks and balances yang menempatkan semua lembaga negara dalam kedudukan setara sehingga terdapat keseimbangan dalam penyelenggaraan negara. Keberadaan Mahkamah Konstitusi merupakan langkah nyata untuk dapat saling mengoreksi kinerja antar lembaga Negara.

Mahkamah Konstitusi adalah bagian dari pelaku kekuasaan kehakiman, disamping Mahkamah Agung, yang merupakan kekuasaan yang merdeka untuk menyelenggarakan peradilan guna menegakan hukum dan keadilan. ${ }^{31}$ Dalam perundang - undangan Indonesia kewenangan MK yang bersifat final digunakan untuk:

1. Menguji undang - undang terhadap Undang - Undang Dasar

2. Memutus sengketa kewenangan lembaga negara yang kewenangannya diberikan oleh Undang - Undang Dasar

3. Memutus pembubaran partai politik

4. Memutus perselisihan tentang hasil pemilihan umum

5. Memberikan putusan atas pendapat DPR mengenai dugaan pelanggaran oleh Presiden dan/atau Wakil Presiden. ${ }^{32}$

Mengingat sifatnya, peluang munculnya pelaksanaan kewenangan Mahkamah Konstitusi dalam ketiga hal jauh lebih kecil daripada peluang munculnya pelaksanaan

\footnotetext{
${ }^{30} \mathrm{http}: / /$ en.wikipedia.org/wiki/Constitution_interpretation, diakses tanggal 20 Mei 2010.

${ }^{31}$ Pasal 24 Ayat (1) UUD 1945

${ }^{32}$ I Dewa Gede Palguna, Mahkamah Konstitusi, judicial Review, dan Welfare State, Sekretariat Jenderal dan

Kepaniteraan Mahkamah Konstitusi, 2008, hlm 9.
} 
kewenangan judicial review. Salah satu sebabnya adalah karena persoalan legal standing yaitu orang atau pihak yang oleh undang - undang diakui memiliki kedudukan hukum untuk mengajukan permohonan sebagai pemohon dihadapan Mahkamah Konstitusi. Alasan lain menempatkan peran Mahkamah Konstitusi dengan kewenangan judicial review-nya untuk membangun budaya taat pada konstituusi adalah karena judicial review merupakan sarana yang melaluinya warga Negara mrndapatkan pemulihan hak - haknya dari pemerintahnya yang bersifat opresif atau menindas. Judicial review juga sekaligus merupakan sarana bagi peradilan guna mencegah dan mengontrol penyalahgunaan kekuasaan yang dilakukan pemerintah. ${ }^{33}$

Menurut ketentuan Pasal 24 Ayat (2) UUD 1945, Mahkamah Konstitusi Indonesia adalah salah satu pelaku kekuasaan kehakiman yang kedudukannya sederajat dengan Mahkamah Agung. Walaupun secara structural kedudukannya sederajat dengan lembaga Negara yang lain, secara fungsional dan implicit hanya Mahkamah Konstitusi yang mempunyai kewenangan tertinggi untuk menafsirkan UUD 1945 yang mempunyai kekuatan hukum mengikat. Mahkamah Konstitusi dibentuk adalah untuk mengawal konstitusi, yaitu agar benar - benar tercermin dan ditaati dalam praktek sehingga cita - cita dimaksud dapat diwujudkan. ${ }^{34}$

Dibentuknya Mahkamah Konstitusi Indonesia melalui perubahan ketiga UUD 1945, adalah sejalan dengan perubahan terhadap Pasal 1 UUD 1945 yaitu cita - cita untuk mewujudkan Indonesia sebagai Negara hukum yang demokratis sebagai sekaligus sebagai Negara demokrasi yang berdasarkan atas hukum, sebagaimana di amanatkan oleh alinea keempat Pembukaan UUD 1945. Pembentukan Mahkamah Konstitusi, yaitu UUD 1945, agar benar - benar tercermin dan ditaati dalam praktik sehingga cita - cita dimaksud dapat diwujudkan.

Perkara-perkara uji konstitusionalitas UU terhadap UUD 1945 di MK mengakibatkan terjadinya perubahan UUD 1945. Perubahan jenis ini juga dijelaskan oleh Wheare sebagai perubahan melalui judicial interpretation. sehingga dapat dikelompokkan ada dua jenis putusan dalam proses uji konstitusional. Pertama, putusan yang menimbulkan makna baru

\footnotetext{
${ }^{33}$ Lee Bridges, Judicial Review in Perspective, Cavendish Publishing Limited, Breat Britain, 1995, hlm 7

${ }^{34}$ I Dewa Gede Palguna, Op Cit, hIm 145.
} 
terhadap teks UUD 1945. Kedua, putusan yang menyebabkan batalnya pasal-pasal atau seluruh ketentuan UU itu sendiri.

Pada perkara No. 008/PUU-II/2004 mengenai uji konstitusional UU No. 23 Tahun 2003 tentang Pemilihan Umum Presiden dan Wakil Presiden terhadap UUD 1945 terdapat penafsiran MK yang mengubah secara tidak langsung teks UUD 1945 itu sendiri. Pasal 6 Ayat (1) UUD 1945 menyatakan:

"Calon presiden dan calon wakil presiden harus seorang warga negara Indonesia sejak kelahirannya dan tidak pernah menerima kewarganegaraan lain karena kehendaknya sendiri, tidak pernah mengkhianati negara, 'serta mampu secara rohani dan jasmani' untuk melaksanakan tugas dan kewajiban sebagai Presiden dan Wakil Presiden”

Kalimat mampu secara rohani dan jasmani' didefenisikan oleh MK dengan tafsir: 'bahwasanya calon presiden dan wakil presiden harus dalam kondisi sehat secara rohani dan jasmani dalam melaksanakan tugas dan kewajiban kenegaraan dimaksud' (Putusan No. 008/PUU-II/2004 halaman 28). Secara tekstual tentu saja terdapat perbedaan yang jelas antara kata 'mampu secara rohani dan jasmani' dengan 'harus dalam kondisi sehat' secara rohani dan jasmani. Melalui Putusan ini, MK telah melakukan perubahan secara textual meaning terhadap Pasal 6 Ayat (1) UUD $1945 .{ }^{35}$

Dalam perkara No. 005/PUU-IV/2006 mengenai uji konstitusionalitas UU No. 22 Tahun 2004 tentang Komisi Yudisial terhadap UUD 1945, Hakim Konstitusi memberikan penafsiran terhadap makna hakim yang dicantumkan Pasal 24 B ayat (1) UUD 1945. MK dalam amarnya tidak memasukkan Hakim Konstitusi sebagai bagian dari kata 'hakim' dalam ketentuan Pasal 24 B UUD 1945. Sebaliknya menurut putusan MK tersebut Hakim Agung merupakan bagian dari Pasal 24 B UUD 1945.

Putusan MK tersebut secara tidak langsung telah mengubah bunyi Pasal $24 \mathrm{~B}$ Ayat (1) UUD 1945 dari berbunyi (original meaning): "Komisi Yudisial bersifat mandiri yang berwenang mengusulkan pengangkatan hakim agung dan mempunyai wewenang lain dalam rangka menjaga dan menegakkan kehormatan, keluhuran martabat, serta perilaku hakim", menjadi bermakna (textual meaning): "Komisi Yudisial bersifat mandiri yang berwenang mengusulkan pengangkatan hakim agung dan mempunyai wewenang lain dalam

\footnotetext{
${ }^{35}$ Feri Amsari dan Saldi Isra, Op.Cit ,hlm. 127
} 
rangka menjaga dan menegakkan kehormatan, keluhuran martabat serta perilaku hakim, kecuali Hakim Konstitusi ”.

Menurut Refly Harun posisi tafsir konstitusi yang memberi makna pada UUD 1945 pada dasarnya lebih tinggi dari undang-undang karenanya fungsi tafsir tersebut hampir sama dengan penjelasan dari UUD. Deny Indrayana berpendapat bahwa dalam hal tafsir MK memberikan makna baru terhadap UUD maka putusan tersebut tidak dapat disamakan dengan penjelasan UUD 1945, fungsinya hanyalah sebagai sebuah tafsir semata. Senada dengan Deny Indrayana, Zainal Arifin Mochtar juga tidak 'berani' terlalu jauh mengklasifikasikan putusan MK dalam hal memberikan makna yang berbeda dengan UUD. Walaupun Deny dan Zainal juga mengakui bahwa tafsir MK tersebut berlaku mengikat kepada seluruh elemen di bawah ketentuan konstitusi. Sedangkan dalam hal putusan MK mengubah atau membatalkan suatu bagian atau keseluruhan dari UU, maka Refly Harun, Deny Indrayana dan Zainal Arifin Mochtar sepakat bahwa putusan itu berlaku sebagaimana undang-undang. ${ }^{36}$

\section{SIMPULAN DAN SARAN}

\subsection{SIMPULAN}

Menutup $\mathrm{BAB}$ ini dengan merefleksikan sebuah peringatan yang diberikan oleh Dicey tentang bahaya akibat "kurangnya perhatian terhadap hukum konstitusi seperti yang benar benar terjadi pada saat ini " yang menjadi arah pembicaraan studinya tentang gagasan freemand dalam buku The Growth of English.$^{37}$ Tanpa mengenal konstitusi lebih lanjut mustahil akan melakukan suatu perubahan kearah yang lebih baik dan dibutuhkan rakyat. Hal ini terjadi dikala kaum-kaum mayoritas menjadi pengambil kebijakan dan membuat atau merubah Konstitusi untuk menenangkan hakiki pribadinya. Namun ujungnya mendompleng makna konstitusi sebagai payung utama pelindung rakyat sehingga akhirnya disaat tujuan Individunya tercapai maka konstitusi hanya menjadi barang mati dan tidak ada harganya.

Perubahan konstitusi secara informal memberikan warna baru dalam perubahan konstitusi suatu Negara. Walaupun perubahan dilakukan berdasarkan kebiasaan ketatanegaraan yang tidak tertulis akan tetapi mempunyai kekuatan hukum yang mengikat

${ }^{36}$ Ibid, hlm. 130

${ }^{37}$ A.V. Dicey, Pengantar Studi hukum konstitusi (Introduction to the study of the law of the Constitution), Bandung: Nusamedia, 2007 
dan ditaati sebagai landasan berpijak dalam menjalankan pemerintahan di suatu Negara.Sedangkan perubahan konstitusi melalui putusan hakim, di Indonesia dilakukan dengan pembentukan MK telah memberikanfungsi tafsir konstitusional sehingga dapat menjaga nilai-nilai konstitusi, walaupun perubahan yang dilakukan MK hanyalah textual meaning saja, akan tetapi dalam penjalanan ketatanegaraan member pengaruh yang sangat signifikan, karena putusan MK tersebut seolah-olah menjadi penjelas otentik dari pasal UUD yang dimaksud.

\subsection{Saran}

Perubahan konstitusi secara informal memberikan warna baru sebaiknya tetap berjalan dan dapat memberikan putusan yang menjadi acuan hukum di Indonesia.

\section{DAFTAR PUSTAKA}

\section{Literatur}

A V Dicey, Pengantar Studi hukum konstitusi (Introduction to the study of the law of the Constitution), Bandung: Nusamedia, 2007.

Astim Riyanto, Teori Konstitusi, Bandung: Penerbit Yapemdo, 2000 .

Djoko Soetono, Kuliah Hukum Tata Negara, Jakarta: Penerbit In-Hill-Co, 2006.

I Dewa Gede Palguna, Mahkamah Konstitusi, judicial Review, dan Welfare State, Jakarta; Sekretariat Jenderal dan Kepaniteraan Mahkamah Konstitusi, 2008.

Jawahir Thontowi, Hukum International Kontemporer, Bandung: PT Refika Aditama, 2006.

Jimly Asshiddiqie, Pengantar Ilmu Hukum Tata Negara-Jilid I, Jakarta: Sekjen Mahkamah Konstitusi RI, 2006.

John Z. Loudoe, Menemukan Hukum Melalui Tafsir dan Fakta, Jakarta: Penerbit Bina Aksara, 1985.

John H Garvey and T Alexander Aleinikof, Modern Constitutional Theory, Third Edition, West Publishing Co. St. Paul, Minn, 1994.

K. C. Wheare, 2005, Konstitusi-Konstitusi Modern, Surabaya: Pustaka Eureka.

Lee Bridges, 1995, Judicial Review in Perspective, Cavendish Publishing Limited, Breat Britain.

Moh. Mahfud MD, 2006, Membangun Politik Hukum, Menegakkan Konstitusi, Pustaka LP3ES Indonesia.

Muhammad Ridhwan Indra, SH, 1990,Undang-Undang Dasar 1945 Sebagai Karya Manusia, Jakarta: Pustaka Sinar Harapan.

Vicki C. Jackson dan Mark Tushnet, 1999, Comparative Constitutional Law, New York: New York Foundation Press.

Jurnal Konstitusi Mahkamah Konstitusi Republik Indonesia, Volume 2, Nomor 1, Juli 2005.

Jurnal Konstitusi PUSaKO Universitas Andalas Volume 1. No. 1 November 2008. 
http://www.sinarharapan.co.id/berita/0611/06/opi01.html

http://www.juridica.ee/get_doc.php?id=635

http://en.wikipedia.org/wiki/Judicial_interpretation.

http://www.historyofsupremecourt.org/history/defines/overview.htm http://repositories.cdlib.org/csd/00-05.

http://www.landmarkcases.org/plessy/const_interp.html, http://www.law.umkc.edu/faculty/projects/ftrials/conlaw, http://en.wikipedia.org/wiki/Constitution_interpretation. 